\title{
Perioperative fluids for pediatrics
}

\author{
Kentaro Ouchi*
}

Department of Dental Anesthesiology, Field of Maxillofacial Diagnostic and Surgical Sciences, Faculty of Dental Science, Kyushu University Graduate School, Japan

\begin{abstract}
In recent years, many studies and case reports have shown that hypotonic fluids may lead to serious hyponatremia or hyperglycemia. However, even recently, hypotonic fluid is general acceptance and use for perioperative. The objective of this review is to assess the more appropriate fluids for pediatrics in perioperative period.

Many reports have shown that hypotonic fluids, such as that containing $30.8-74 \mathrm{mEq} / \mathrm{L}$ sodium, decrease blood sodium levels. On the other hand, isotonic fluids included with $140 \mathrm{mEq} / \mathrm{L}$ sodium enabled maintenance of blood sodium concentration, due to its similarity to normal blood sodium concentrations. Solutions with glucose concentration of $5 \%$ are associated with an unacceptably high blood glucose level. In more lower glucose concentration, $2 \%$ are associated with an unacceptably high blood glucose level. There were not hypoglycemia and hyperglycemia with fluids containing $1 \%$ glucose.

In conclusion, isotonic fluids with $1 \%$ glucose help to avoid hyponatremia and hyperglycemia in pediatric and may, therefore, enhance patient safety. Currently, I recommend use of isotonic fluids with $1 \%$ glucose for pediatrics in perioperative period.
\end{abstract}

\section{Introduction}

Maintenance fluid therapy in children is based on Holliday and Segar's recommendations to use hypotonic fluids containing $30 \mathrm{mEq} / \mathrm{L}$ sodium with $5 \%$ glucose [1]. In perioperative for pediatrics, based on these recommendations, hypotonic fluids containing $30.8-90 \mathrm{mEq} / \mathrm{L}$ sodium with 2.6 - 5\% glucose are commonly used; these hypotonic fluids have slightly higher levels of sodium than the Holliday and Segar's recommendations $[2,3]$.

In recent years, many studies and case reports have shown that hypotonic fluids may lead to serious hyponatremia or hyperglycemia [2,4-8]. However, even recently, hypotonic fluid is general acceptance and use for perioperative $[2,3]$.

Table 1 shows fluid that is generally distributed. In this article, I discuss the appropriate fluids for pediatrics in perioperative period.

\section{Sodium concentration}

Many reports have shown that hypotonic fluids, such as those containing 30.8 - $74 \mathrm{mEq} / \mathrm{L}$ sodium, decrease blood sodium levels $[8,9]$. In the perioperative period, the risk of developing hyponatremia is increased because of stress-induced secretion of antidiuretic hormone $[10,11]$. The hyponatremia is associated with considerable morbidity and mortality $[12,13]$, including cerebral edema. In pediatric patients, even a small decrease in sodium levels can lead to cerebral herniation due to the limited room available in the rigid skull to accommodate the swollen brain [10]. In addition, the ability of the pediatric brain to adapt to hyponatremia is poorer than that of adults [14]. Reports have shown that hypotonic fluids cause hyponatremia, with the resultant fall in sodium levels leading to serious neurologic outcomes in 2 of 40 patients who received hypotonic fluids [4]. In this previous report, decrease in sodium from 142 to $128 \mathrm{mEq} / \mathrm{L}$ led to cardiac arrest, and postmortem examination revealed brain cell swelling [4]. Thus, a decrease in sodium levels must be avoided. Reportedly, hypotonic fluids lead hyponatremia or serum sodium reduction [3,15-18]. (Table 2) Contrary, reportedly, in the post-appendectomy period, the use of hypotonic solution $(30.8$
$\mathrm{mEq} / \mathrm{L}$ ) did not increase the risk of hyponatremia when compared to isotonic saline [19]. Moreover, reportedly, when administered at the appropriate maintenance rate, hypotonic solution $(77 \mathrm{mEq} / \mathrm{L})$ did not result in serum sodium reduction during the first 12 hours of fluid therapy in hospitalized children [20].

On the other hand, isotonic fluids included with $140 \mathrm{mEq} / \mathrm{L}$ sodium enabled maintenance of blood sodium concentration, due to its similarity to normal blood sodium concentrations [21]. Recently, It recommended replacing hypotonic fluids with isotonic fluids during the perioperative period in pediatrics [2].

\section{Glucose concentration}

The next topic is the presence/absence of the necessity of administration of glucose during surgery. Surgical stress has been shown to increase blood glucose concentrations without a concomitant increase in plasma insulin concentrations [22]. Thus, despite the use of non-glucose fluids, blood glucose concentrations increase and plasma insulin concentrations decrease in adult patients undergoing surgery [22]. In pediatric patients, on the other hand, surgical stress alone does not increase blood glucose concentrations when non-glucose fluids are used [23]. This indicates a difference in the glucose response to surgical stress between pediatric and adult patients. There are, reportedly, differences in whole body and brain glucose metabolism between these two patient populations; in particular, brain metabolism changes markedly during development [24]. Glucose is essential for the normal brain to function and hypoglycemia exerts important effects on the central nervous system. For example, increases in regional blood flow with a loss of cerebrovascular autoregulation can lead to clinical

Correspondence to: Dr. Kentaro Ouchi, Department of Dental Anesthesiology, Field of Maxillofacial Diagnostic and Surgical Sciences, Faculty of Dental Science, Kyushu University Graduate School, Japan, Tel: +81-92-641-1151; Fax: +81-92-642-6481; E-mail: ken2006anes@yahoo.co.jp

Received: March 28, 2016; Accepted: May 21, 2016; Published: May 25, 2016 
Table 1. Generally distributed major fluids.

\begin{tabular}{|c|c|c|c|c|c|c|c|}
\hline Fluids & Type & Sodium $(\mathbf{m E q} / \mathbf{L})$ & Chloride (mEq/L) & Glucose $(g / L)$ & Lactate $(\mathrm{mEq} / \mathrm{L})$ & Acetate $(\mathrm{mEq} / \mathrm{L})$ & $\mathrm{HCO}_{3-}(\mathrm{mEq} / \mathrm{L})$ \\
\hline $0.22 \%$ saline & Hypotonic & 39 & 39 & 50 & - & - & - \\
\hline $0.45 \%$ saline & Hypotonic & 77 & 77 & 50 & - & - & - \\
\hline $0.53 \%$ saline & Hypotonic & 90 & 70 & 26 & 20 & - & - \\
\hline $0.9 \%$ saline & Isotonic & 154 & 154 & - & - & - & - \\
\hline Acetate ringer & Isotonic & 140 & 115 & 10 & - & 25 & - \\
\hline Bicarbonate ringer & Isotonic & 135 & 113 & - & - & - & 25 \\
\hline
\end{tabular}

Table 2. Serum sodium reduction or hyponatremia by hypotonic fluids.

\begin{tabular}{|c|c|c|c|c|c|c|c|c|}
\hline Study & Subject & $\mathbf{N}$ & $\begin{array}{c}\text { Sodium } \\
\text { concentration of } \\
\text { fluid }(\mathrm{mEq} / \mathrm{L})\end{array}$ & $\begin{array}{l}\text { Pre serum sodium } \\
\quad(\mathrm{mEq} / \mathrm{L})\end{array}$ & $\begin{array}{c}\text { Time until post } \\
\text { measurement } \\
\text { (hour) }\end{array}$ & $\begin{array}{l}\text { Post serum sodium } \\
\quad(\mathrm{mEq} / \mathrm{L})\end{array}$ & $\begin{array}{c}\text { Change of serum } \\
\text { sodium (pre-post) } \\
(\mathrm{mEq} / \mathrm{L})\end{array}$ & $\begin{array}{r}\text { Incidence of } \\
\text { hyponatremia } \\
(\mathbf{N}, \%)\end{array}$ \\
\hline Bito [3] & 4 month (3-12 month) & 25 & 90 & $136.3 \pm 1.8$ & 4 & $135.5 \pm 2.1$ & -0.8 & N/A \\
\hline Ramanathan [15] & ( 2 month - 5 years) & 60 & 30.8 & N/A & 12 & N/A & $-4.2 \pm 6.9$ & $8,13 \%$ \\
\hline Shamim [16] & 54.4 month \pm 31.7 & 30 & 30.8 & $136.3[135.0-137.7]$ & 24 & $129.7[128.3-131.1]$ & -6.6 & $25,83 \%$ \\
\hline \multirow[t]{2}{*}{ Pemde [17] } & 32.0 month $\langle 20.7>$ & 30 & 77 & $139.3<3.3>$ & 12 & N/A & N/A & $11,36 \%$ \\
\hline & 28.3 month $<21.8>$ & 31 & 30.8 & $138.6<3.6>$ & 12 & N/A & N/A & $15,39 \%$ \\
\hline Rey [18] & 56.2 month $<98.3>$ & 62 & $(30-50)$ & $135.9 \pm 3.3$ & 12 & $133.7 \pm 2.7$ & N/A & N/A \\
\hline
\end{tabular}

( ) indicate that maximum and minimum value

[ ] indicate that $95 \%$ confidence interval (CI)

$<>$ indicate that interquartile range (IQR)

\pm indicate that standard deviation

Table 3. Nonesterified fatty acids and ketone bodies concentration that was associated by fluids

\begin{tabular}{|c|c|c|c|c|c|c|c|}
\hline \multirow[t]{2}{*}{ Study } & \multirow[t]{2}{*}{ Subject } & \multirow{2}{*}{$\begin{array}{c}\text { Glucose concentration } \\
\text { of fluids }\end{array}$} & \multirow[t]{2}{*}{$\mathbf{N}$} & \multicolumn{2}{|c|}{ Nonesterified fatty acids } & \multicolumn{2}{|c|}{ Ketone bodies } \\
\hline & & & & During surgery & After surgery & During surgery & After surgery \\
\hline Kambe [22] & 43.0 years \pm 13.8 & $0 \%$ & 18 & Increase & No change & Increase & No change \\
\hline \multirow[t]{3}{*}{ Mikawa [23] } & \multirow[t]{3}{*}{$(1.5-9$ years $)$} & $0 \%$ & 15 & No change & No change & No change & No change \\
\hline & & $2 \%$ & 15 & No change & No change & No change & No change \\
\hline & & $5 \%$ & 15 & No change & No change & No change & No change \\
\hline \multirow[t]{3}{*}{ Nishina [27] } & \multirow[t]{3}{*}{ (1 - 11 month) } & $0 \%$ & 20 & Increase & Increase & Increase & Increase \\
\hline & & $2 \%$ & 20 & No change & No change & No change & No change \\
\hline & & $5 \%$ & 20 & No change & No change & No change & No change \\
\hline
\end{tabular}

( ) indicate that maximum and minimum value

\pm indicate that standard deviation

symptoms and permanent neuronal damage. On the other hand, hyperglycemia can also be detrimental to the brain. Hyperglycemia is associated with worsening of brain ischemia and anoxia [25]. Hyperglycemia can induce diuresis and consequently dehydration and electrolyte disturbances, especially in immature tubular function patients such as small preterm infants [26]. As 5\% glucose solutions are associated with an unacceptably high blood glucose level, solutions with a lower glucose concentration have been assessed in pediatric anesthesia [7]. Since even solutions with a lower glucose concentration of $2 \%$ are associated with an unacceptably high blood glucose level, solutions with an even lower glucose concentration have been assessed in pediatric anesthesia $[7,23]$. Reportedly, there were not hypoglycemia and hyperglycemia with fluids containing $1 \%$ glucose [21].

It is well known that a severe lack of glucose enhances lipolysis, leading to ketogenesis. Use of non-glucose fluids increased plasma concentrations of nonesterified fatty acids and ketone bodies, at the end of and after surgery [27]. It indicates lipid mobilization. Table 3 shows nonesterified fatty acids and ketone bodies concentration that was associated by fluids. Use of $1 \%$ glucose fluids reportedly maintains plasma glucose concentrations within the physiological range and prevents the development of ketoacidosis and metabolic acidosis, according to a study which assessed plasma $\mathrm{pH}$ but not ketone bodies [21]. However, the effects of $1 \%$ glucose fluids on plasma ketone bodies and nonesterified fatty acids concentrations in perioperative period have not been reported. If evaluate these biochemical parameters, these may have revealed a lack of glucose with the use of $1 \%$ glucose solutions. Thus, future study is expected to clarify plasma ketone bodies and nonesterified fatty acids concentrations with $1 \%$ glucose fluids.

\section{Conclusion}

Isotonic fluids with $1 \%$ glucose help to avoid hyponatremia and hyperglycemia in pediatric and may, therefore, enhance patient safety. Currently, I recommend use of isotonic fluids with $1 \%$ glucose for pediatrics in perioperative period.

\section{References}

1. Holliday MA, Segar WE (1957) The maintenance need for water in parenteral fluid therapy. Pediatrics 19: 823-832. [Crossref]

2. Way C, Dhamrait R, Wade A, Walker I (2006) Perioperative fluid therapy in children: a survey of current prescribing practice. Br J Anaesth 97: 371-379. [Crossref]

3. Bito K, Higuchi S, Omura A, Kaneda Y, Otaki R, et al. (2015) [Hypotonic Versus Isotonic Electrolyte Solution for Perioperative Fluid Therapy in Infants]. Masui 64: 294-300. [Crossref]

4. Hoorn EJ, Geary D, Robb M, Halperin ML, Bohn D (2004) Acute hyponatremia related to intravenous fluid administration in hospitalized children: an observational study. Pediatrics 113: 1279-1284. [Crossref]

5. Moritz ML, Ayus JC (2005) Preventing neurological complications from dysnatremias in children. Pediatr Nephrol 20: 1687-1700. [Crossref] 
6. Murat I, Dubois MC (2008) Perioperative fluid therapy in pediatrics. Paediatr Anaesth 18: 363-370. [Crossref]

7. Paut $\mathrm{O}$, Lacroix F (2006) Recent developments in the perioperative fluid management for the paediatric patient. Curr Opin Anaesthesiol 19: 268-277. [Crossref]

8. Choong K, Kho ME, Menon K, Bohn D (2006) Hypotonic versus isotonic saline in hospitalised children: a systematic review. Arch Dis Child 91: 828-835. [Crossref]

9. Wang J, Xu E, Xiao Y (2014) Isotonic versus hypotonic maintenance IV fluids in hospitalized children: a meta-analysis. Pediatrics 133: 105-113. [Crossref]

10. Arieff AI (1998) Postoperative hyponatraemic encephalopathy following elective surgery in children. Paediatr Anaesth 8: 1-4 [Crossref]

11. Fraser CL, Arieff AI (1997) Epidemiology, pathophysiology, and management of hyponatremic encephalopathy. Am J Med 102: 67-77. [Crossref]

12. Assen AAD, Vandergheynst F, Nguyen T, Taccone FS, Melot C (2014) Hyponatremia at the Emergency Department: a case-control study. Minerva Anestesiol 80: 419-428. [Crossref]

13. Gritti P, Lanterna LA, Rotasperti L, Filippini M, Cazzaniga S, et al. (2014) Clinical evaluation of hyponatremia and hypovolemia in critically ill adult neurologic patients: contribution of the use of cumulative balance of sodium. J Anesth 28: 687-95 [Crossref]

14. Sarnaik AP, Meert K, Hackbarth R, Fleischmann L (1991) Management of hyponatremic seizures in children with hypertonic saline: a safe and effective strategy. Crit Care Med 19: 758-762. [Crossref]

15. Ramanathan S, Kumar P, Mishra K, Dutta AK (2016) Isotonic versus Hypotonic Parenteral Maintenance Fluids in Very Severe Pneumonia. Indian J Pediatr 83: 27-32. [Crossref]

16. Shamim A, Afzal K, Ali SM (2014) Safety and efficacy of isotonic $(0.9 \%)$ vs. hypotonic $(0.18 \%)$ saline as maintenance intravenous fluids in children: a randomized controlled trial. Indian Pediatr 51: 969-974. [Crossref]

17. Pemde HK, Dutta AK, Sodani R, Mishra K (2015) Isotonic intravenous maintenance fluid reduces hospital acquired hyponatremia in young children with central nervous system infections. Indian J Pediatr 82: 13-18. [Crossref]

18. Rey C, Los-Arcos M, Hernandez A, Sanchez A, Diaz JJ, Lopez-Herce J (2011) Hypotonic versus isotonic maintenance fluids in critically ill children: a multicenter prospective randomized study. Acta Paediatr 100: 1138-1143. [Crossref]

19. Valadao MC, Piva JP, Santana JC, Garcia PC (2015) Comparison of two maintenance electrolyte solutions in children in the postoperative appendectomy period: a randomized, controlled trial. J Pediatr (Rio J) 91: 428-434. [Crossref]

20. Saba TG, Fairbairn J, Houghton F, Laforte D, Foster BJ (2011) A randomized controlled trial of isotonic versus hypotonic maintenance intravenous fluids in hospitalized children. BMC Pediatr 11: 82 [Crossref]

21. Sumpelmann R, Mader T, Eich C, Witt L, Osthaus WA (2010) A novel isotonic-balanced electrolyte solution with $1 \%$ glucose for intraoperative fluid therapy in children: results of a prospective multicentre observational post-authorization safety study (PASS). Paediatr Anaesth 20: 977-981. [Crossref]

22. Kambe N, Tanaka K, Kakuta N, Kawanishi R, Tsutsumi YM (2014) The influence of glucose load on metabolism during minor surgery using remifentanil-induced anesthesia. Acta Anaesthesiol Scand 58: 948-954. [Crossref]

23. Mikawa K, Maekawa N, Goto R, Tanaka O, Yaku H, Obara H (1991) Effects of exogenous intravenous glucose on plasma glucose and lipid homeostasis in anesthetized children. Anesthesiology 74: 1017-1022. [Crossref]

24. Loepke AW, Spaeth JP (2004) Glucose and heart surgery: neonates are not just smal adults. Anesthesiology 100: 1339-1341. [Crossref]

25. Wass CT, Lanier WL (1996) Glucose modulation of ischemic brain injury: review and clinical recommendations. Mayo Clin Proc 71: 801-812. [Crossref]

26. Leelanukrom R, Cunliffe M (2000) Intraoperative fluid and glucose management in children. Paediatr Anaesth 10: 353-359. [Crossref]

27. Nishina K, Mikawa K, Maekawa N, Asano M, Obara H (1995) Effects of exogenous intravenous glucose on plasma glucose and lipid homeostasis in anesthetized infants. Anesthesiology 83: 258-263. [Crossref]

Copyright: (C2016 Ouchi K. This is an open-access article distributed under the terms of the Creative Commons Attribution License, which permits unrestricted use, distribution, and reproduction in any medium, provided the original author and source are credited. 